\title{
不擋乱畑地土壤を用いた土䁃中の陽イオン交換実験
}

\author{
広城 吉成* ·横山 拓史 $*$ ・神野 健二** \\ 和田 信一郎 $* * *$. 市川勉 $* * * *$. 佐藤 貞夫 $* * * * *$
}

\section{A Study on Cation Exchange Reaction in Undisturbed Soil Columns of Farm Land}

\author{
Yoshinari HIROSHIRO *, Takushi YOKOYAMA * \\ Kenji JINNO $^{* *}$, Shin-Ichiro WADA *** \\ Tsutomu ICHIKAWA $* * * *$ and Sadao SATOH $* * * * *$
}

\begin{abstract}
In order to model the transport of fertilizer components from soil surface to groundwater in farm land, a preliminary experiment, in which a $\mathrm{KCl}$ solution was infiltrated through undisturbed soil columns, was carried out and cation exchange capacity (CEC) and selectivity coefficients $\left(\mathrm{K}_{\mathrm{Ca} / \mathrm{M}},{\mathrm{M}: \mathrm{Na}^{+}}^{+}\right.$, $\mathrm{K}^{+}, \mathrm{Mg}^{2+}$ ) were determined.

The soil columns consisted of two kinds of soils: a top layer of soil containing organic material and a lower layer of decomposed granite soils. The CEC values of the two soil layers were5-20 and3-7 meq/100g of dry soil, respectively. In the columns, the exchange reaction of $\mathrm{Ca}^{2+}$ with $\mathrm{K}^{+}$was dominant. The $\mathrm{K}_{\mathrm{Ca} / \mathrm{K}}$ was approximated as a function of the adsorbed potassium molar fraction, whereas the $\mathrm{K}_{\mathrm{Ca} / \mathrm{Mg}}$ was constant at about 1.2 .
\end{abstract}

Key Words: Undisturbed Soil Column, Cation Exchange Capacity, Selectivity Coefficient.

1.はじめに

近年、農耕地に施肥される肥料によりその地域の 地下水水質が影響を受けることが指摘されており、
最適施肥量の見積りや肥料物質の土壤中における輸 送メカニズムを明らかにすることが不可欠になって いる。

農耕地に施肥される肥料の主要構成成分は窒素、

*九州大学 教養部 Colledge of General Education, Kyushu University

**九州大学 工学部 Faculty of Engineering, Kyushu University

***九州大学 農学部 Faculty of Agriculture, Kyushu University

*****州東海大学 工学部 Faculty of Engineering, Kyushu Tokai University

*****長崎県庁 Nagasaki Prefectural Government 
リン酸、カリウムなどであり、これら各成分が水の 浸透に伴って土壤表面から地下に移動する過程はそ れぞれ異なる。畑地に施肥される窒素の形態は主に アンモニア態窒素、硝酸態窒素であるが、アンモニ ア態窒素はそのほとんどが硝化されて硝酸態窒素に 変わり土壤にほとんど吸着されることなく移動す る。一方、リン酸は土壤に強く保持されるため ${ }^{11}$ 地 下水水質に大きな影響を及ぼさないが、カリウムの ような陽イオンは以前から土壤に吸着していたナト リウム、カルシウム、マグネシウムなどと陽イオン 交換反応を起こし、相互に影響を及ぼし合いながら 地下に移動していく。

従来、単一の化学種で吸着等の化学反応が無視で きる場合には土壤に応じた適切な分散係数を用いて 移流分散方程式を解くことで十分な成果が得られて いる2 が、近年問題となっている農薬、肥料あるい は有機塩素系化合物等の污染物質は、土壤や地下水 中に打ける種々の鉱物質や腐植物質あるいは微生物

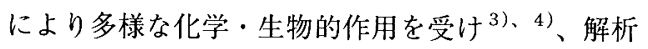
のモデルにも複雑な表現が必要となっている。化学 的作用のうち吸着に関しては、例えば土壤の吸着サ イトに吸着される化学種の濃度が土壤溶液の濃度に 比例すると仮定し解析することでほぼよい結果が得 られているが5)、カリウムなどのような陽イオン交 換を伴う物質が土壤に負荷された場合には、他の陽 イオンとの間の化学反応を考虑した地下水中での物 質輸送モデルの開発が必要となる。

さて、不飽和浸透流と多成分化学反応過程とを考 慮した水理化学的物質輸送解析 ${ }^{6}$ を行うためにはモ デルを検証する基礎的データが必要となるが、現在 のところ多くは 2 成分間のみのイオン交換モデルで しかも選択係数についてはそれを一定值として与え 解析している場合が多く、本報のような多成分のイ オン交換を対象にし、かつ深さに応じた選択係数を 用いて解析している例は見当らない。従って本報で は上記解析を行うための基礎実験としてカリウムが 畑地に施肥された場合に起こる陽イオン交換反応に よる陽イオンの挙動を把握し、固相と液相間の化学 的作用を論ずる際に不可欠となる陽イオン交換容量 や選択係数を評価するために、実際の畑地から土壤 を不摚乱状態で採取し室内カラム実験を行い、モデ ル化の際に必要となる輸送のメカニズムについて考 察した。

\section{2. 不擋乱畑地土堹採取地域の概要}

\section{1 土地利用状況}

不擋乱烟地土壤を採取した地域を図一1に示す。記 号 $\mathrm{F}$ は土畩採取地点、記号 $\mathrm{W}$ はこの地域に点在す る井戸を示す。この地域は 4 月から 9 月にかけては 水田、10月から 3 月までは水田の裏作としての畑に 変わる。畑では主にキャベツなどが栽培されている。 また、ビニールハウスでは一年を通してほうれん草 などの野菜が栽培されている。なお、この地域にお ける地下水中の硝酸態窒素や溶存酸素などの季節的 変動については文献 7 )を参考にされたい。

\section{2 地下水流向および地質》}

この地域で推定される地下水流向は濦-1に示すよ うに概ねW1からW6の方向に流れているものと推 測される。また今回採取した不摚乱土壌の地質状況 は地表面から $20 \mathrm{~cm}$ 程度までが畑地土䁃であり、 $20 \mathrm{~cm}$ から $1 \mathrm{~m}$ 前後までがマサ土となっている。

\section{3. 不摚乱畑地土壤の採取について}

本報では現実に起こる水の浸透過程、イオン交 換をよりよく反映させるために不摚乱土壌を用いカ ラム実験を行った。以下にその採取作業手順を述べ る。

図-1に示した $\mathrm{F}$ 地点はビニールハウスに挟まれ た畑地で、烟地の一部を深さ $1 \mathrm{~m} 、$ 一辺 $50 \mathrm{~cm}$ 程度 の矩形土柱塊になるように掘り、予め準備しておい た塩化ビニール製の円筒(長さ $5 \mathrm{~cm}$ 每に切断し、そ

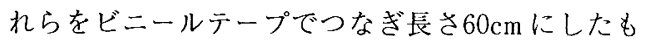
ので、内径は $75 \mathrm{~mm}$ )に挿入できるように丁寧に削り 取り、土柱上部から徐々に差し込んだ。次に土䁃か らの水分蒸発を防ぐため、円筒上部から溶かしたパ ラフィンを流し込み、パラフィンが固化した時点で 円筒底部の土壤を金属へラで切り取りビニール袋に 入れて密封した。この方法で長さ $60 \mathrm{~cm}$ のカラム 55 本 を採取した。な㧍、表-1には目視観察の結果から、 カラム内の土壤は上層部の畑地土銥(Top Soil) と下 部のマサ土壤 (Decomposed Granite Soils)の 2 種類 であるとし、それらの土の土質特性を示している。 また、採取した土壤の不飽和特性についてはVan Genuchten が提案した式8)を用いて不飽和特性值を 決定した。表-2にその結果を示している。 


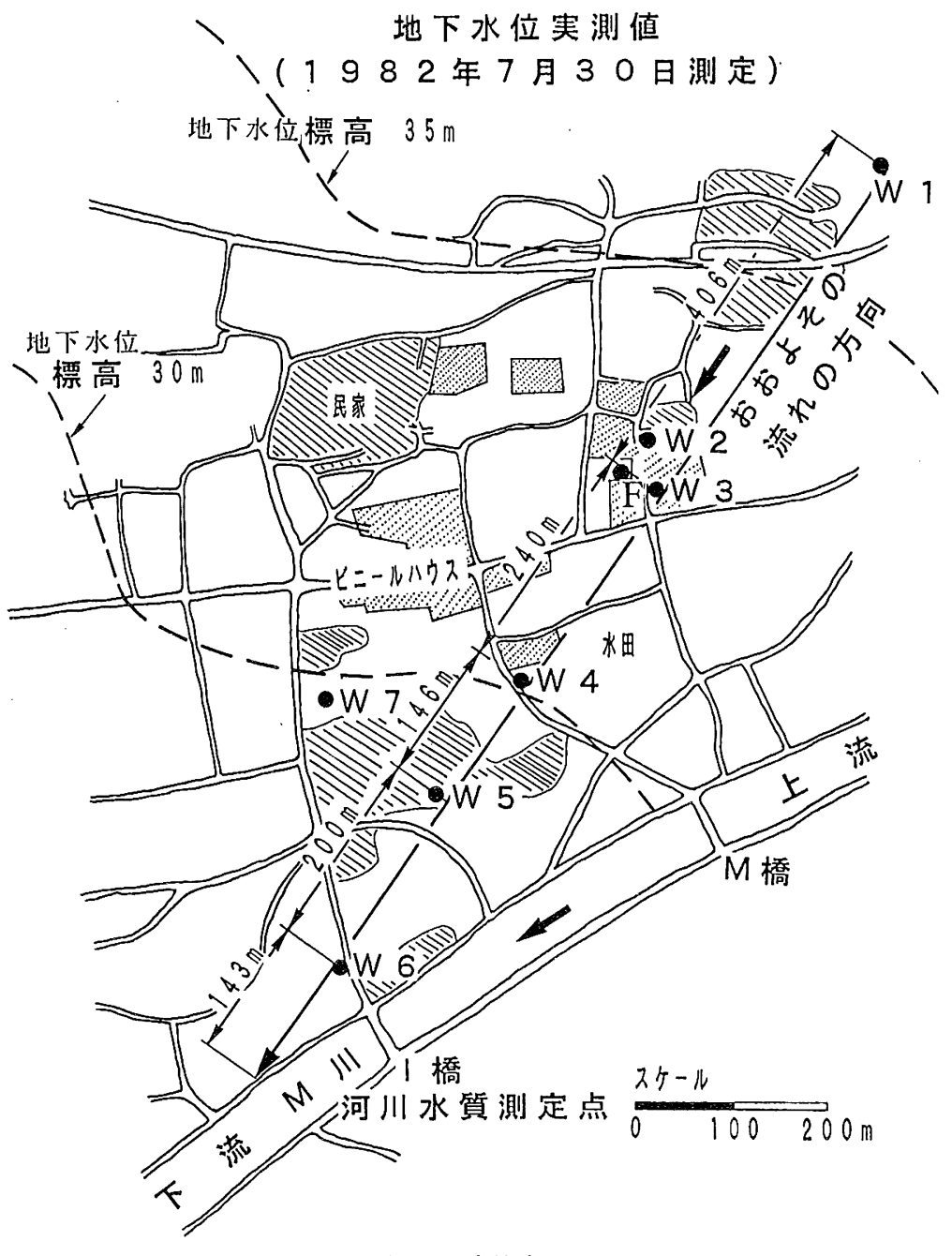

図一 1 土壤採取地点付近の平面図

Fig-1 Location of soil sampling site

表一 1 土の土質特性值

Table-1 Soil properties

\begin{tabular}{|c|c|c|}
\hline Index & Top Soil & $\begin{array}{c}\text { Lower Soil } \\
\text { (Decomposed Granite Soils }\end{array}$ \\
\hline permeability $\quad(\mathrm{cm} / \mathrm{s})$ & $1.59 \times 10^{-3}$ & $1.55 \times 10^{-3}$ \\
\hline liquid limit (\%) & 47.9 & 43.1 \\
\hline plastic limit $(\%)$ & 35.2 & 34.9 \\
\hline $\begin{array}{ll}\text { density } & \left(\mathrm{g} / \mathrm{cm}^{3}\right)\end{array}$ & 2.690 & 2.758 \\
\hline water content (\%) & 33.7 & 43.2 \\
\hline porosity & 53.1 & 58.8 \\
\hline
\end{tabular}




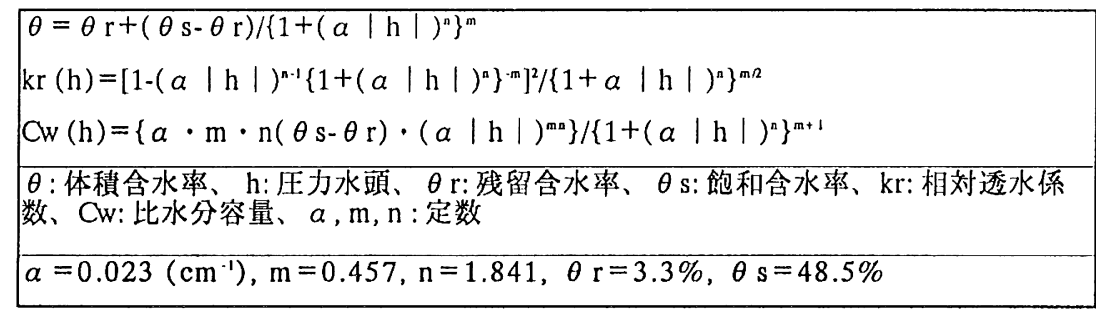

\section{4. 室内カラム実験の概略}

\section{1 実験装置および実験方法}

実験装置の概略を図-2に示す。実験の際にはカラ ムの上部 2 セグメント $(10 \mathrm{~cm})$ と底部 1 セグメント $(5$ $\mathrm{cm})$ を切り離し、カラム全長を $45 \mathrm{~cm}$ ( 9 セグメント) とした。次にカラム上面から純水を約 $41 \mathrm{ml} / \mathrm{h}$ の流 量で滴下させ、カラム底部からの流出流量が-定に なるまで続け、これが定常状態になった後、 $\mathrm{KCl}$ 溶 液 $(\mathrm{KCl}-\mathrm{K}$ 濃度で約 $9000 \mathrm{mg} / \mathrm{l})$ を同じ流量で 5 本の

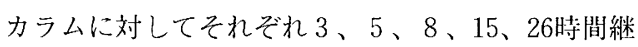
続して滴下させた。各滴下時問が経過した後、即座 にカラム 9 セグメントを分割解体し、ポリエチレン 製の袋にそのセグメント内の土壤の大部分を採取し たあと、その袋の中の土壤を擋乱させ化学分析に使 用した。また、残りの土銥を用いて解体後の含水比 を測定した。その結果を表-3に示す。

次に、各カラム各セグメントの解体時における目 視観察による土壤の種類について、カラム 1 では上 部3セグメント $(15 \mathrm{~cm})$ までがマサ土に比べ黑色の畑 地上層土壤が卓越した状態であり、以下、カラム 2

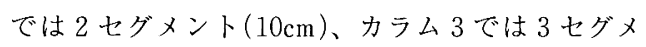
ント $(15 \mathrm{~cm})$ 、カラム 4 では 2 セグメント $(10 \mathrm{~cm})$ ま でがマサ土に比べて黒色の畑地上層土壤が卓越した 状態であった。またカラム5では全セグメントとも マサ土主体の土壤であった。

\section{2 分析方法}

ポリエチレン製の袋に採取した各セグメントの摚 乱した土壤の一部を用いて遠心分離により土壤間隙 水を抽出し、原子吸光法 (使用機器:Nippon JarrellAsh AA-8500)により土壤間隙水中の陽イオン $\left(\mathrm{Na}^{+}\right.$, $\left.\mathrm{K}^{+}, \mathrm{Mg}^{2+}, \mathrm{Ca}^{2+}\right)$ 濃度を測定した。また、塩化物イ

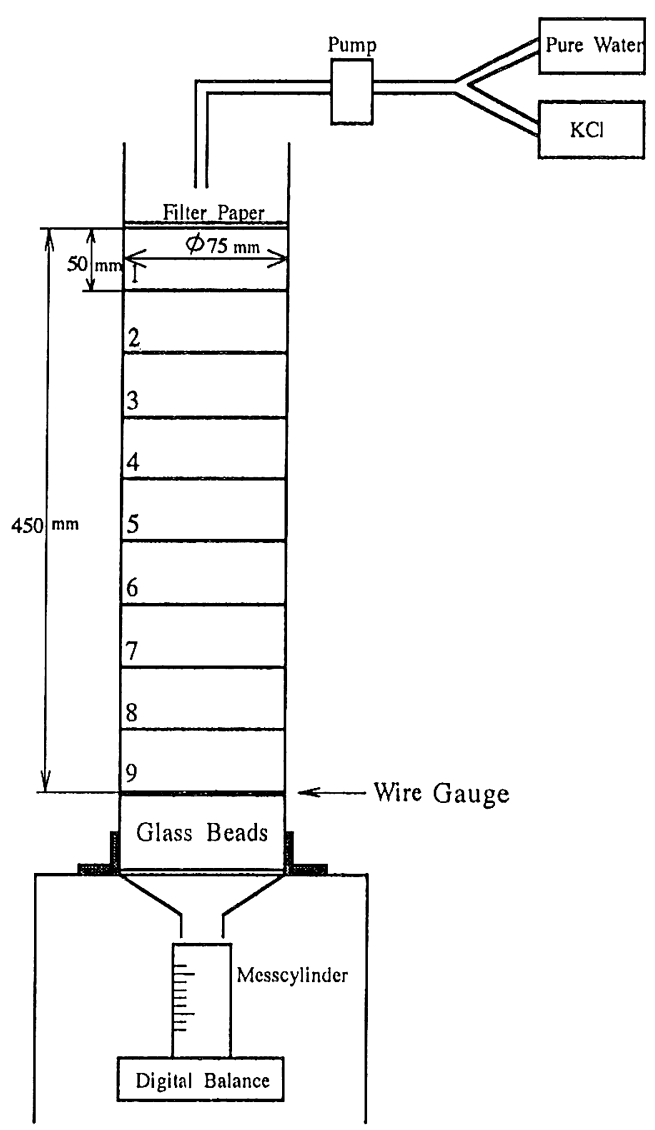

図一 2 実験装置の概略図

Fig-2 Experimental column equipment

オンはイオンクロマトグラフィー(使用機器:DION EX-QIC)で測定した。次に遠心分離後の土鏆を用い て、振とう浸出法 ${ }^{9}$ により土壤の交換性陽イオン含 量を測定し、この方法で得られた交換性陽イオンの 合計量を陽イオン交換容量(CEC)とした。 
表一 3 分割解体後の土壤含水比 (\%)

Table-3 Water content of each soil segment at end of experiments

\begin{tabular}{|c|c|c|c|c|c|}
\hline segment No. No. & Column-1 & Column-2 & Column-3 & Column-4 & Column-5 \\
\hline 1 & 40.6 & 49.2 & 39.2 & 41.9 & 47.6 \\
\hline 2 & 47.6 & 52.4 & 50.0 & 48.3 & 44.2 \\
\hline 3 & 52.8 & 46.1 & 49.6 & 47.4 & 41.8 \\
\hline 4 & 52.3 & 45.0 & 48.6 & 46.3 & 41.1 \\
\hline 5 & 52.5 & 44.2 & 47.3 & 42.3 & 40.9 \\
\hline 6 & 52.5 & 45.2 & 48.6 & 40.3 & 39.7 \\
\hline 7 & 42.8 & 45.6 & 45.5 & 39.6 & 38.9 \\
\hline 8 & 42.5 & 44.4 & 43.6 & 39.8 & 39.0 \\
\hline 9 & 42.5 & 43.3 & 42.2 & 40.0 & 39.3 \\
\hline
\end{tabular}

(セグメント番号の1はカラム上而である)

(Segment No.1 indicates the top segment of the column.)

\section{5. 結果と考察}

\section{1 塩化物イオン濃度の分布}

$\mathrm{KCl}$ 溶液をそれぞれのカラムで3時問 (column-1)、 5 時間 (column-2)、 8 時間 (column-3)、15 時間 (column-4)、26時閒 (column-5)継続して滴下させた ときの各カラム液相中の塩化物イオンの濃度分布を 図-3に示す。この図から $\mathrm{KCl}$ 溶液滴下時間が長く
なるにつれて、カラム底部に向かって塩化物イオン が浸透している様子が判る。この塩化物イオンの浸 透状況から、今回用いたどのカラムも大きな孔隙な どはなかったと考えられる。

\section{2 陽イオン濃度の分布}

各滴下時間に対する陽イオンの濃度分布を図-4 図-8に示す。これらによると $\mathrm{K}^{+}$の移動は塩化物イ

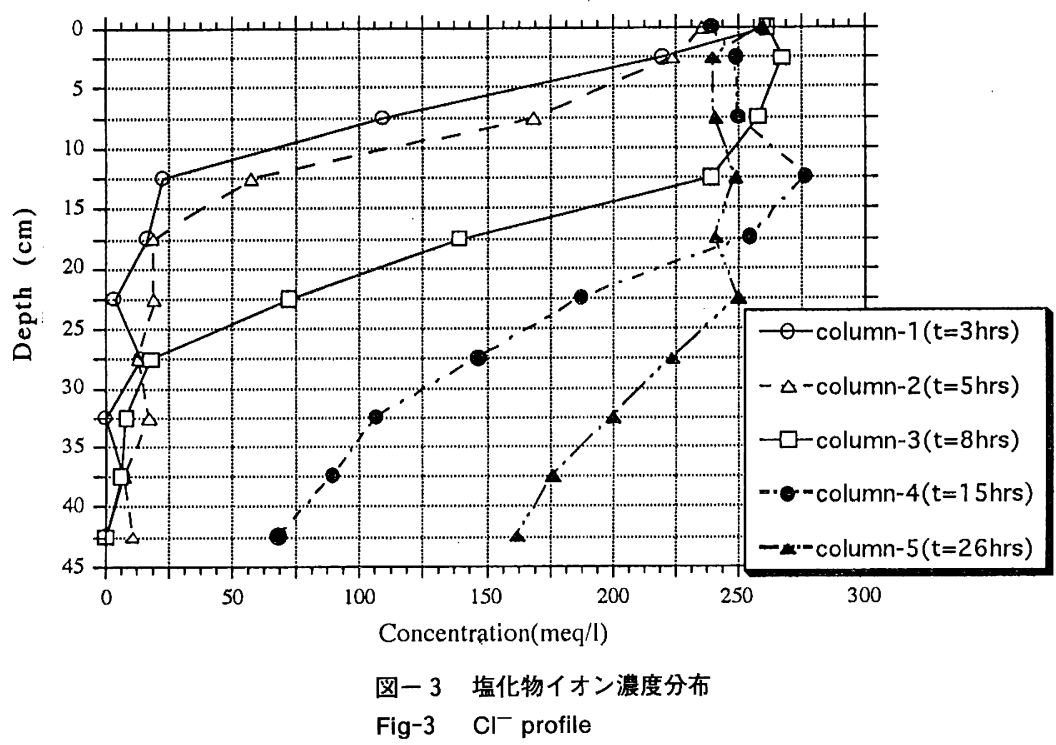




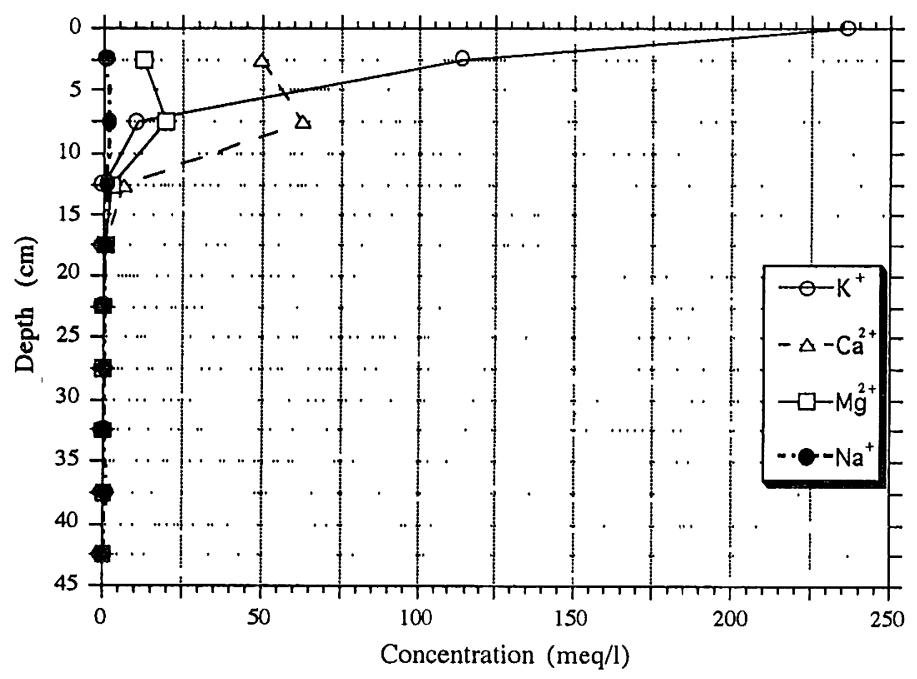

図一4 陽イオン溇度分布 (column-1)

Fig-4 Cation profile (column-1)

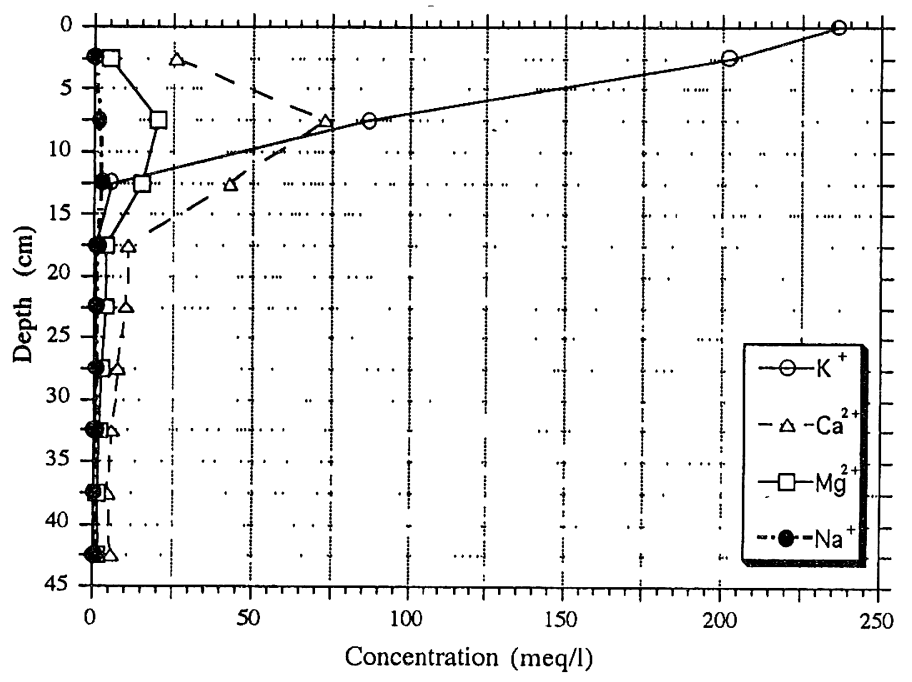

図一 5 陽イオン浱度分布 (column-2)

Fig-5 Cation profile (column-2)

オンのそれに比べて遅れが生じていることが読み取 れる。このことは、 $\mathrm{K}^{+}$が陽イオン交換反応によっ て固相に保持されたために起こったもので、はじめ に固相に保持されていた $\mathrm{Na}^{+}, \mathrm{Mg}^{2+}, \mathrm{Ca}^{2+}$ は高濃 度の $\mathrm{K}^{+}$負荷により陽イオン交換し、液相中に放出 されたものと考えられる。また、 $\mathrm{KCl}$ 溶液滴下時開
が長くなるにつれて、 $\mathrm{Mg}^{2+}, \mathrm{Ca}^{2+}$ のピークがカラ ム底部へ移動しているが、いずれの継続時問の場合 も $\mathrm{Na}^{+}$の顕著なピークが認められないことから、 今回採取した土畩には交换性 $\mathrm{Na}^{+}$があまり含まれ ていなかったと考えられる。 


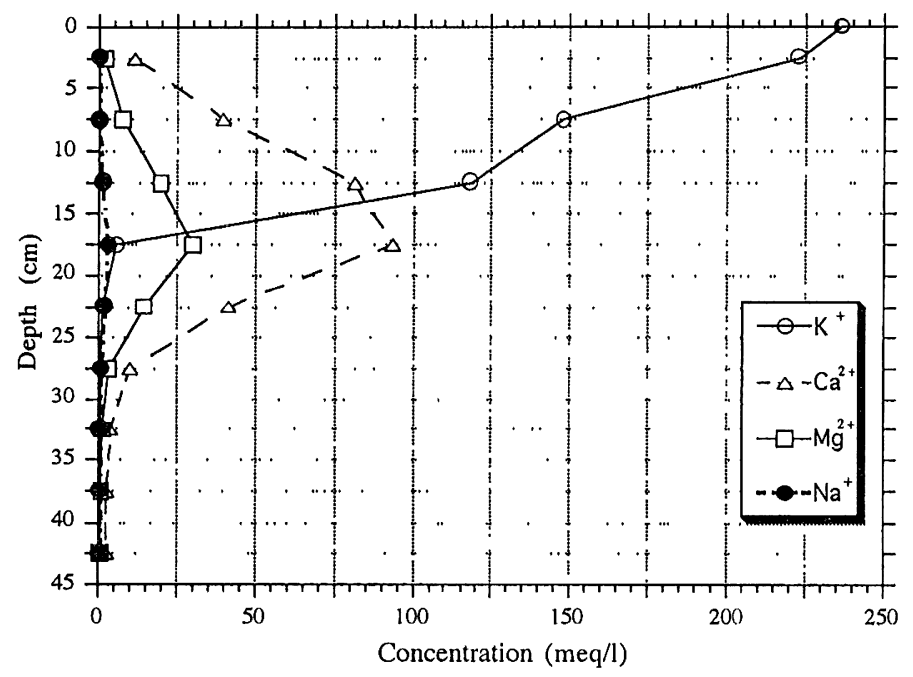

図一 6 陽イオン濃度分布 (column- 3)

Fig-6 Cation profile (column-3)

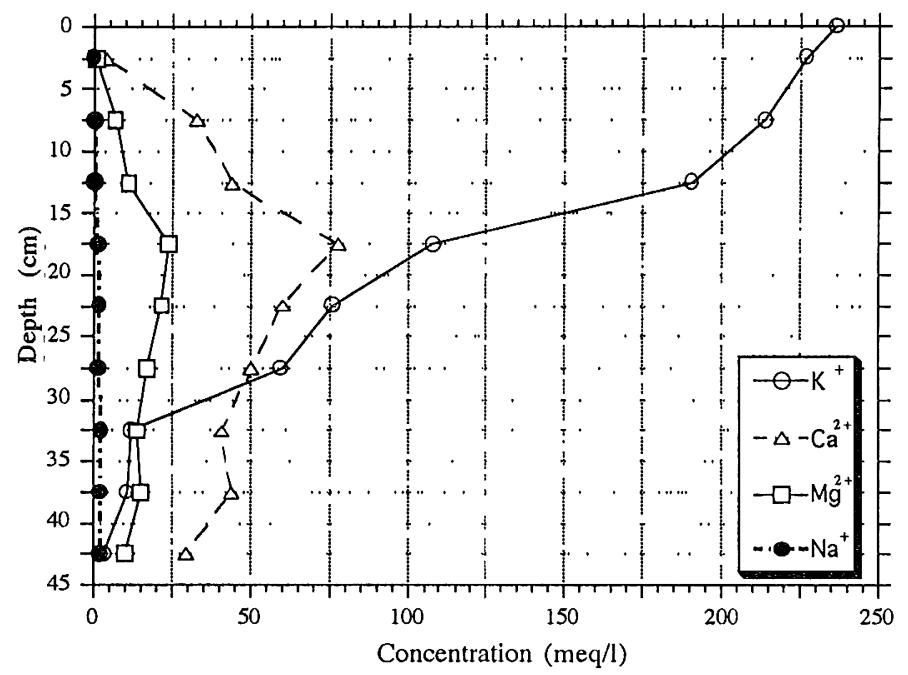

図一７陽イオン濃度分布 (column- 4)

Fig-7 Cation profile (column-4)

\section{3 液相中における陰・陽イオンの当量濃度}

各カラム各セグメントの液相中における陰イオン と陽イオン濃度の当量関係を网-9に示す。ここでは 塩化物イオン以外の陰イオンの濃度は極端に低かっ たので、陰イオンは塩化物イオンのみであるとした。 図中の○は塩化物イオン濃度、ムは㙅化物イオン濃
度から陽イオン $\left(\mathrm{Na}^{+}, \mathrm{K}^{+}, \mathrm{Mg}^{2+}, \mathrm{Ca}^{2+}\right)$ の合計濃度 を差し引いてプロットしたものであり、また横䌷の 1 ～ 9 までの数字はカラムセグメント番号を表して いる。この図から概ね㓌イオンと陽イオン間の当量 は等しいと判断できる。なお、当量のずれが大きい 箇所も若干見られるが、高濃度の塩化物イオン、カ 


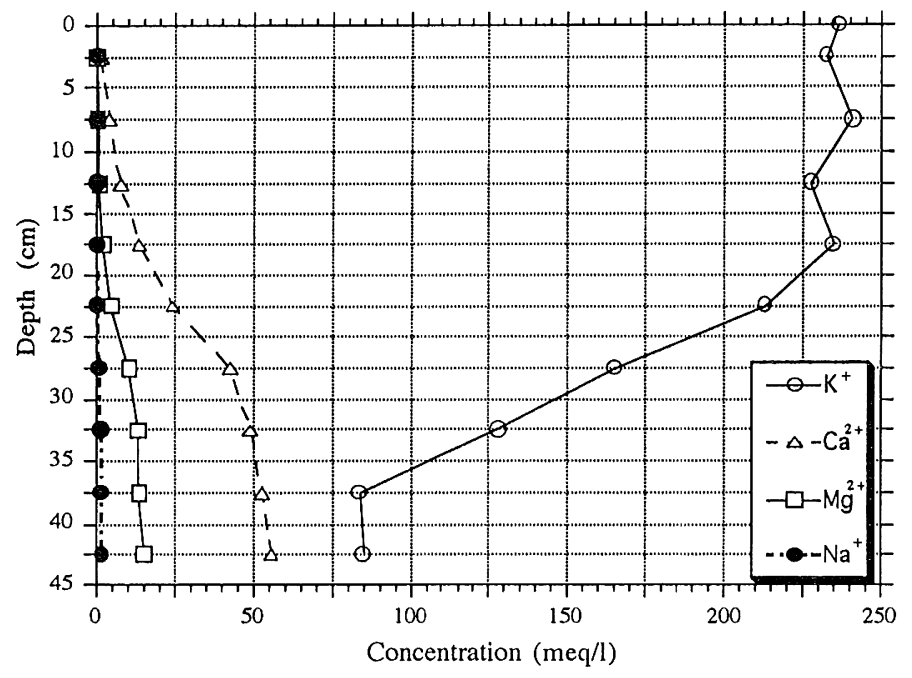

図ー8 陽イオン濃度分布 (column- 5)

Fig-8 Cation profile (column- 5)

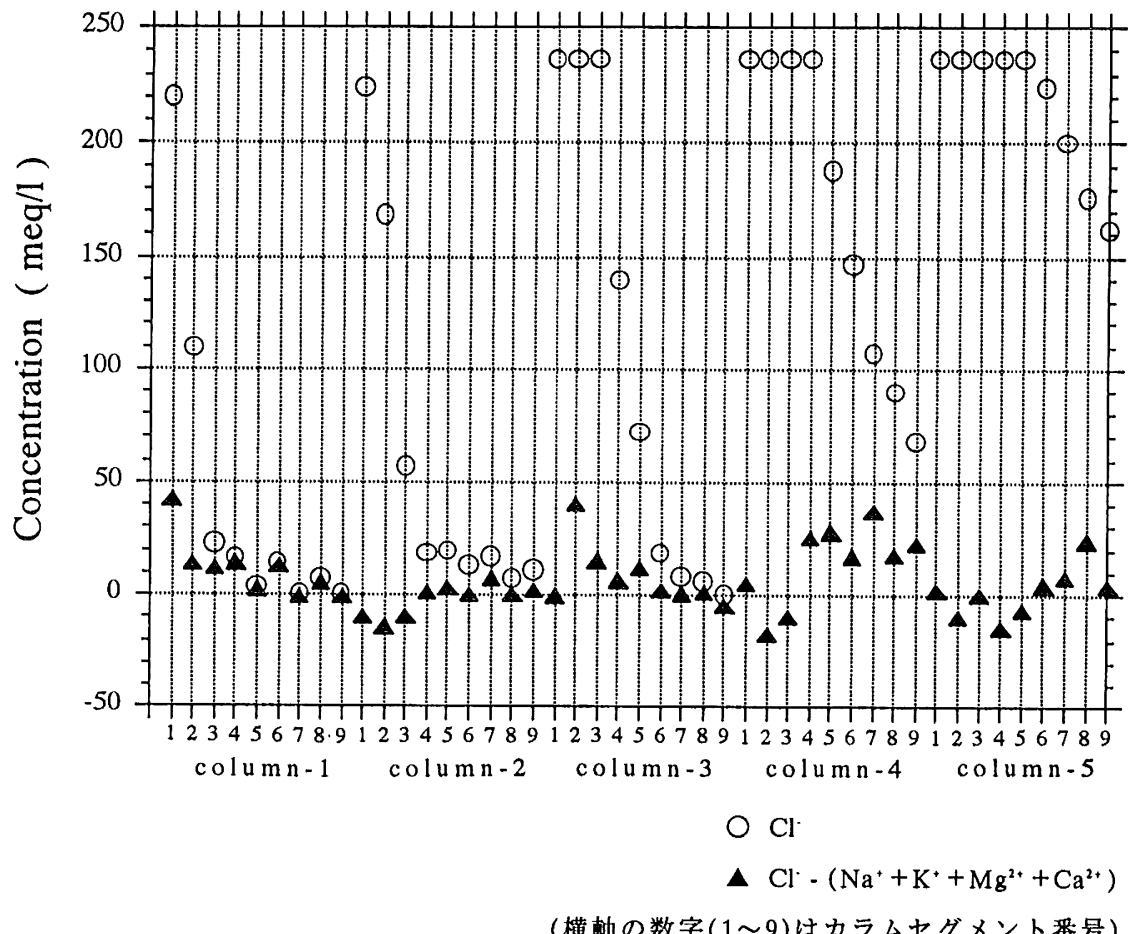

图一 9 液相中における陰・陽イオンの当量濃度

Fig-9 Balance of anion and cation concentrations in pore water

(The abscissa $(1 \sim 9)$ indicates column-segment number.) 
リウムイオンなどは希积倍率を大きくして測走する 必要があり、分析測定に起因する䛊差によるものと 考えられる。

\section{4 陽イオン交換容量}

土壤の CEC は単位重量の土壤による $1 \mathrm{M} 、 \mathrm{pH} 7$ の酢酸アンモニウム浴液からのアンモニウム吸着量
として操作的に定義されている ${ }^{10)}$ 。しかし本報で は $\mathrm{pH}$ を調節していない $\mathrm{KCl}$ を浸透させたこと、こ の土壤中には $\mathrm{Na}^{+}, \mathrm{K}^{+}, \mathrm{Mg}^{2+}, \mathrm{Ca}^{2+}$ 以外の陽イオ ンは実質的には含まれていないことを考慮し、これ ら4種の陽イオンの吸着量の合計をもって土壤のC E Cとした。

网-10〜図-14は、KC 1 溶液滴下時間ごとのカラ

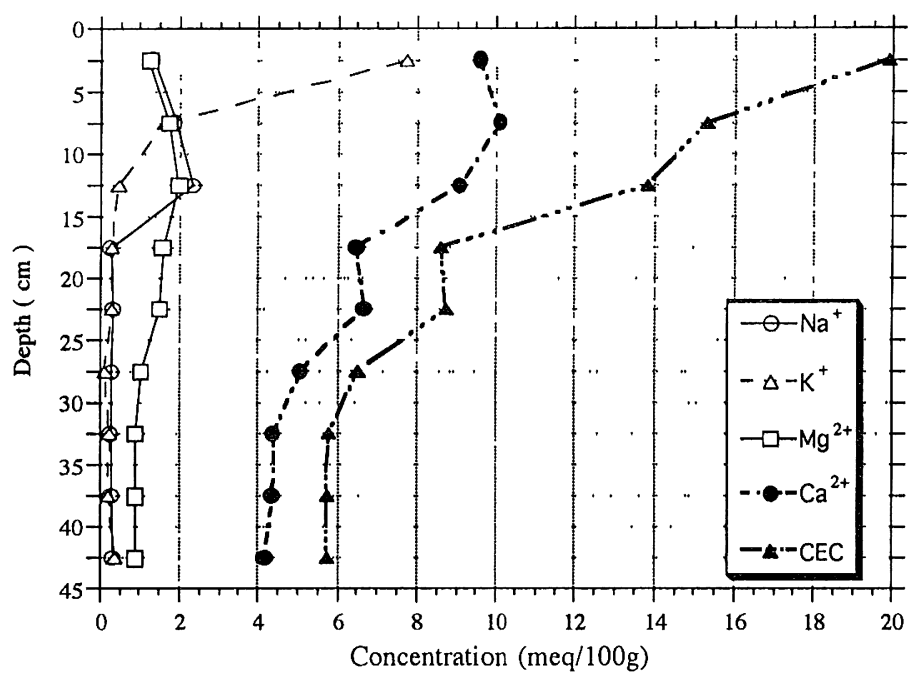

図一10 固相中の陽イオン濃度分布 (column-1)

Fig-10 Profile of the adsorbed cations on the soil (column-1)

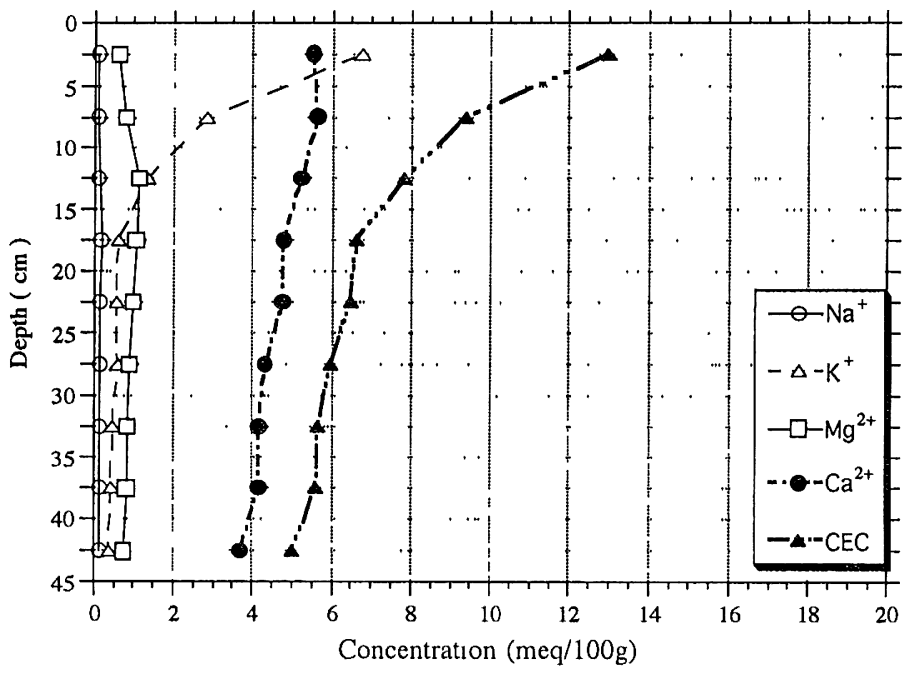

図一11固相中の陽イオン濃度分布 (column- 2)

Fig-11 Profile of the adsorbed cations on the soil (column-2) 


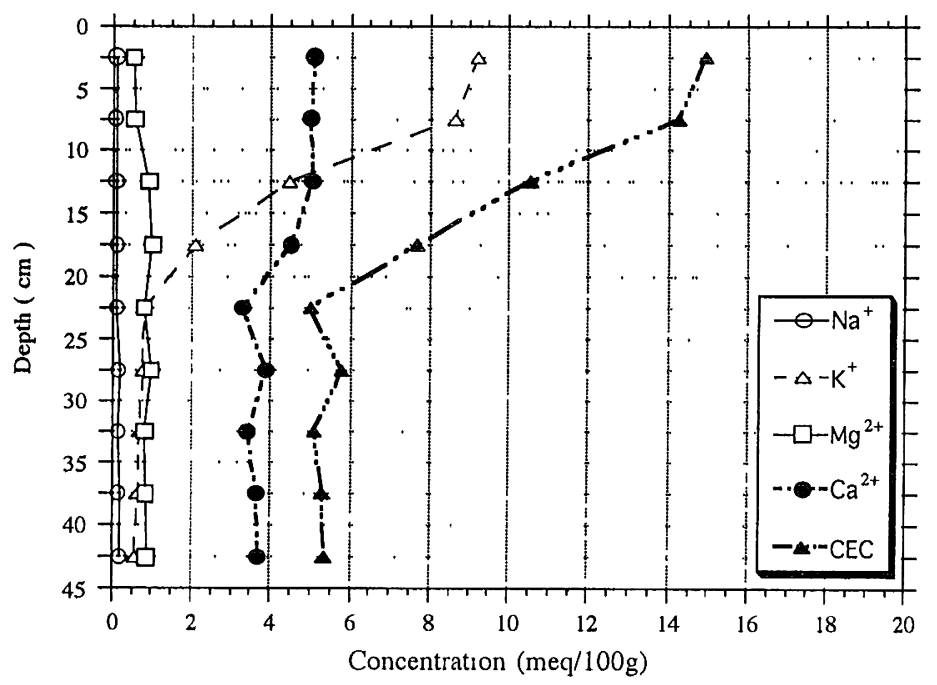

図一12 固相中の陽イオン嶩度分布 (column- 3)

Fig-12 Profile of the adsorbed cations on the soil (column- 3 )

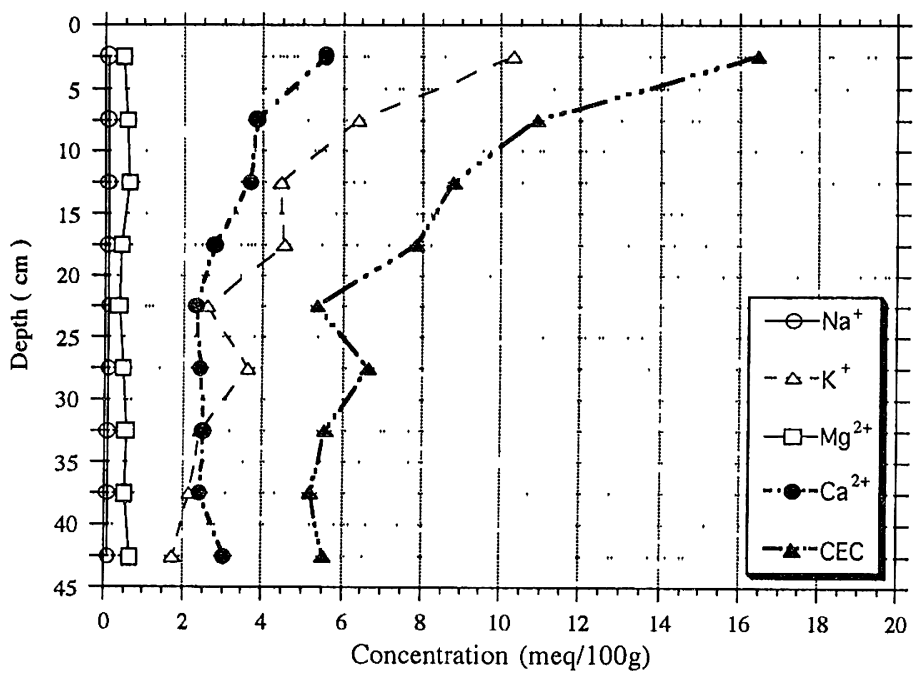

図一13 固相中の陽イオン蕽度分布 (column- 4)

Fig-13 Profile of the adsorbed cations on the soil (column-4)

ムセグメント内における固相中陽イオン濃度の分布 を示している。これらの図より KC 1 溶液滴下時問 が長くなるにつれて、当初固相に最も多く吸着され ていた $\mathrm{Ca}^{2+}$ が $\mathrm{K}^{+}$に置き換わっており、この系で 生じている反応は主としてイオン交換によるもので あるといえる。
また、网-15は各カラムの深さお向における血イ オン交換容量(以下、CEC)の分布を示しているが、 この図から実験に用いた畑地土壤の CECは、深さ 約 $20 \mathrm{~cm}$ までは 5 20 ( meq $/ 100 \mathrm{~g})$ であり、 $20 \mathrm{~cm}$ 以深 では 3〜7 (meq/100g)の值を示した。媣さ約 $20 \mathrm{~cm}$ までの CEC は $20 \mathrm{~cm}$ 以深の CEC より値が大きく、ば 


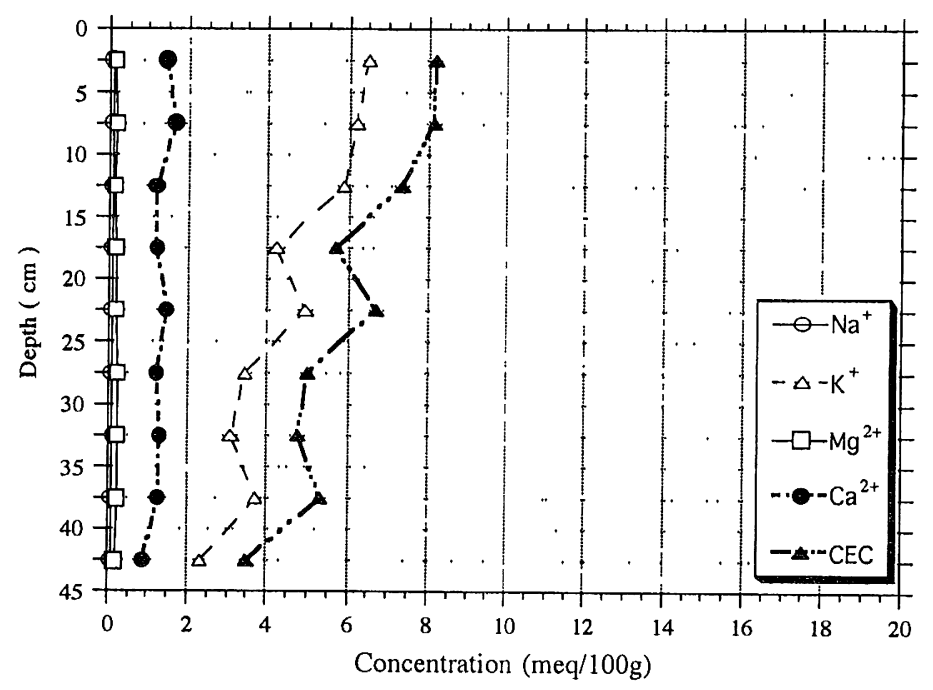

図ー14 固相中の陽イオン濃度分布 (column- 5)

Fig-14 Profile of the adsorbed cations on the soil (column- 5 )

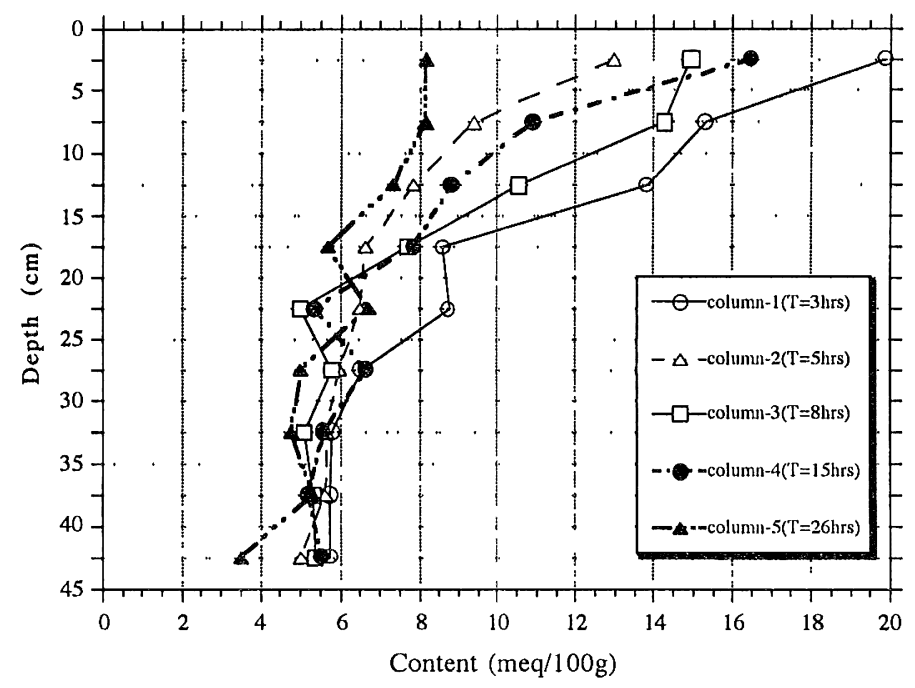

図ー15 深さ方向における CEC 分布

Fig-15 CEC profile

らつきの幅も大きい。土壤の主なイオン交換・吸着 体は粘土鉱物と腐植であり 土壤の表層部は黒色を呈していたことから、カラム 深さ約 $20 \mathrm{~cm}$ までの部分の腐植含量が高かったこと によると考えられる。

\section{5 選択係数6)、11)}

固相と液相間の晹イオン交換反応は、例えば $\mathrm{K}^{+}$ 濃度が液相中で増加した場合に、以前から吸着して いた $\mathrm{Ca}^{2+}$ が固相から離脱して $\mathrm{K}^{+}$とイオン交換す る。この反応は周相を「とすると次式で表される。 


$$
2 \mathrm{I}^{2}-\mathrm{K}^{+}+\mathrm{Ca}^{2+}=\mathrm{\Gamma}-\mathrm{Ca}^{2++}+2 \mathrm{~K}^{+}
$$

この交換平衡に対する選択係数は次式で表される：

$$
\mathrm{K}_{\mathrm{Ca} / \mathrm{K}}=\frac{\mathrm{X}_{\mathrm{Ca}}\left[\mathrm{K}^{+}\right]^{2}}{\mathrm{X}_{\mathrm{K}}^{2}\left[\mathrm{Ca}^{2+}\right]}
$$

同様に $\mathrm{Na}^{+}$と $\mathrm{Ca}^{2+}, \mathrm{Mg}^{2+}$ と $\mathrm{Ca}^{2+}$ に刘して

$$
\begin{aligned}
\mathrm{K}_{\mathrm{Ca} / \mathrm{Na}} & =\frac{\mathrm{X}_{\mathrm{Ca}}\left[\mathrm{Na}^{+}\right]^{2}}{\mathrm{X}_{\mathrm{Na}}^{2}\left[\mathrm{Ca}^{2+}\right]} \\
\mathrm{K}_{\mathrm{Ca} / \mathrm{Mg}} & =\frac{\mathrm{X}_{\mathrm{Ca}}\left[\mathrm{Mg}^{2+}\right]}{\mathrm{X}_{\mathrm{Mg}}\left[\mathrm{Ca}^{2+}\right]}
\end{aligned}
$$

のように表わすことができる。ここに、 $\mathrm{K}_{\mathrm{Ca} / \mathrm{K}}, \mathrm{K}_{\mathrm{Ca} /}$ $\mathrm{Na}, \mathrm{K}_{\mathrm{Ca} / \mathrm{Mg}}$ は $\mathrm{K}^{+}, \mathrm{Na}^{+}, \mathrm{Mg}^{2+}$ を基準にした $\mathrm{Ca}^{2+}$ の 選択係数であり、次に $\mathrm{X}_{\mathrm{Na}}, \mathrm{X}_{\mathrm{K}}, \mathrm{X}_{\mathrm{Mg}}, \mathrm{X}_{\mathrm{Ca}}$ は固相に おける交換性陽イオンのモル分率である。［］は 次式に示すようにそれぞれの化学成分の溶液中の濃 度に対する活動度で、濃度と活動度係数の䅣で与え られる。すなわち、イオン強度をIとして：

$$
\mathrm{I}=(1 / 2) \sum \mathrm{C}_{\mathrm{i}} \mathrm{Z}_{\mathrm{i}}^{2}
$$

（iに関する総和は陽・陰イオンの全てが対象） を算定し、次いでDavies の式 ${ }^{12)}$ に基づく次式：

$$
\log _{10} G_{i}=-0.5115 Z_{i}^{2}(\sqrt{I} /(1+\sqrt{I})-0.3 I)
$$

により活動度係数 $\mathrm{Gi}$ の算定を行う。例えば $\mathrm{K}^{+}$の 活動度は $\left[\mathrm{K}^{+}\right]=\mathrm{G}_{\mathrm{K}} \cdot\left(\mathrm{K}^{+}\right)$となる。ここで、 $\left(\mathrm{K}^{+}\right)$ は $\mathrm{K}^{+}$の測定濃度 $(\mathrm{mol} / \mathrm{l})$ 、即ち全 $\mathrm{K}^{+}$濃度であり、 zi はi イオンの電荷である。いま、対象としている 各カラム各段の土壤の CEC を一定とし、交換可能 な陽イオンの総和がCECに等しいとすると、次式 が成り立つ。

$$
\mathrm{X}_{\mathrm{Na}}+\mathrm{X}_{\mathrm{K}}+\mathrm{X}_{\mathrm{Mg}}+\mathrm{X}_{\mathrm{Ca}}=1
$$

選択係数は固相と液相間における陽イオンの分配 の予測を行う上で重要なパラメータで、実用的には 固相表面に墕イオンどうしがどのように選択的に保 持されるかを示す数值である。以下に選択係数の算
尘手順を示す。

各カラム各セグメントに抒ける液相での $\mathrm{Na}^{+}$, $\mathrm{K}^{+}, \mathrm{Mg}^{2+}, \mathrm{Ca}^{2+}$ 濃度と陰イオン濃度を式( 5 )に代 入しイオン強度 $\mathrm{I}$ を求め、式( 6 )から活動度係数 $\mathrm{Gi}$ を算定する。この Gi と各陽イオン濃度との積をと ると活動度が計算される。次に、カラム各セグメン トの土壤による各陽イオンの吸着量(同じくモル単 位)で除すことにより土壤に吸着した陽イオンのモ ル分率を求める。以上のようにして得られた值をそ れぞれ式( 2 )、（3)、（4）に代入し選択係数を算定 する。

なお、今国の実験における選択係数は静的状態で 測定されるバッチ試験の選択係数とは異なり動的状 態で測定された選択係数であるため、本報で得られ た選択係数は実動選択係数と呼ぶべき性格のもので あることを断っておく。

\section{6 実験結果}

各陽イオン $\left(\mathrm{Na}^{+}, \mathrm{K}^{+}, \mathrm{Mg}^{2+}\right)$ を基準にした $\mathrm{Ca}^{2+}$ の選択係数とそれぞれのモル分率との関係を図-16、 図-17、図-18に示す。な挍、刚中の記号○やにに付 した数字はカラムーセグメント番号である。は表 層部、○は下層部(マサ土)の土壤に対する選択係数 である。なお、図-16〜18でカラム 1 におけるそれ ぞれの選択係数については、液相中での陽イオン濃 度が極端に低かったため記載を省略した。

汹-16の $\mathrm{K}_{\mathrm{Ca} / \mathrm{Na}}$ と $\mathrm{Na}^{+}$のモル分率との関係では、 この実験で用いた土壤の $\mathrm{Na}^{+}$含量は低かったので、 $\mathrm{KCl}$ 滴下時閒に関わりなくどのカラムのどの位置に おいても吸着 $\mathrm{Na}^{+}$のモル分率は 0.08 を越えること はなかった。 $\mathrm{K}_{\mathrm{Ca} / \mathrm{Na}}$ は0.007〜0.4の簌囲に分布し $\mathrm{Na}^{+}$吸着量との間に相関はなく、また腐植に富む層 位とマサ土の部分の間の差もみられなかった。 $\mathrm{K}_{\mathrm{Ca} / \mathrm{Na}}$ の值にこのような大きなばらつきがあるの は、一つには濃度、吸着量の測定值の相対誤差が大 きかったことによるほか、選択係数の值が $\mathrm{Na}^{+}$吸 着量のみでなくその他の陽イオンの吸着量に複雑に 依存していることによる可能性もある。しかしいず れにせよ、 $\mathrm{Na}^{+}$の存在量が低いためにこの種の土壤 における陽イオンの移動をモデル化するにあたって は $\mathrm{Na}^{+}$を無視することも可能である。

図-17に $\mathrm{K}_{\mathrm{Ca} / \mathrm{K}}$ と $\mathrm{K}^{+}$のモル分率との関係を示す。 ここで同じモル分率で比較すると、腐植に富む層位 の $\mathrm{K}_{\mathrm{Ca} / \mathrm{K}}$ 值の方が明らかに大きい傾向がある。これ 


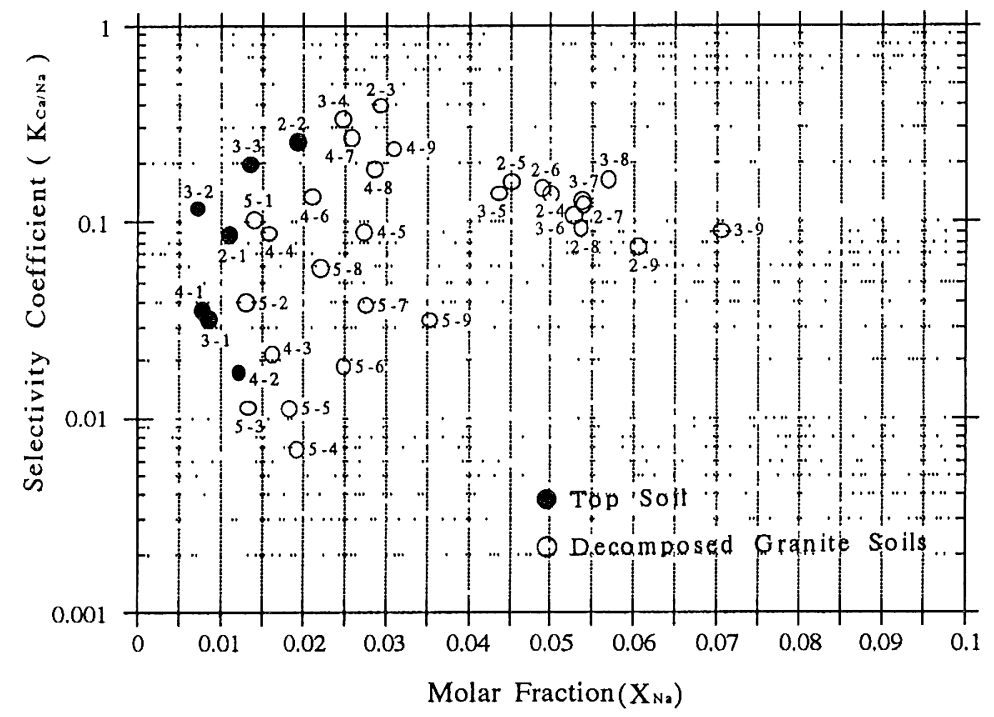

图-16 $\quad \mathrm{K}_{\mathrm{Ca} / \mathrm{Na}}$ と $\mathrm{X}_{\mathrm{Na}}$ の関係

Fig-16 The relationship between selectivity coefficient $\left(\mathrm{K}_{\mathrm{Ca} / \mathrm{Na}}\right)$ and molar fraction $\left(\mathrm{X}_{\mathrm{Na}}\right)$

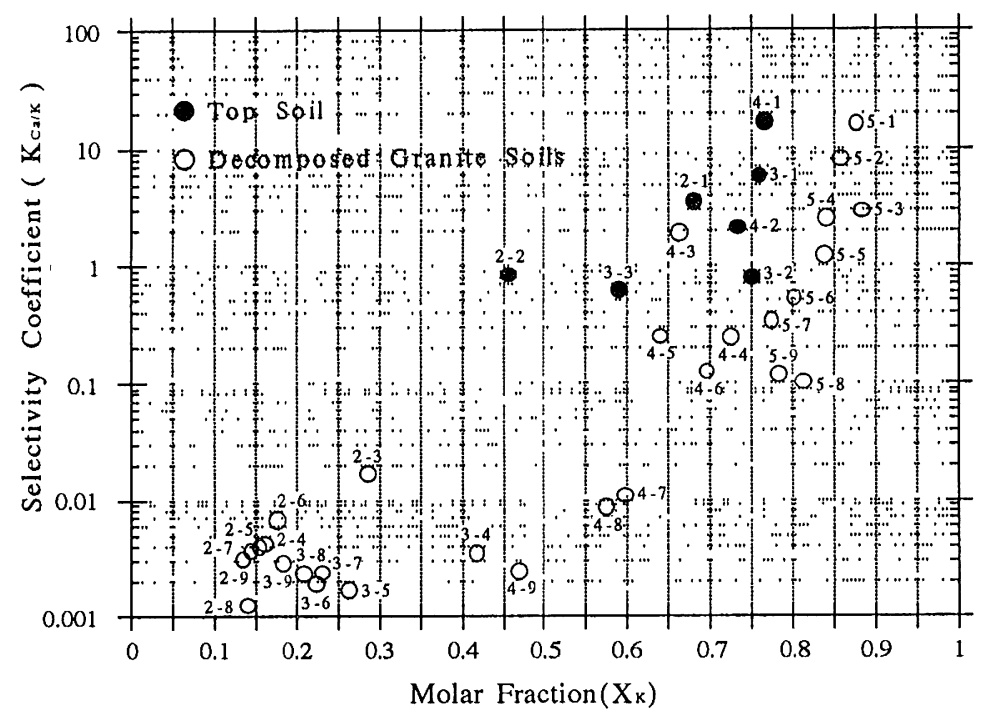

図一17 $\mathrm{K}_{\mathrm{Ca} / \mathrm{K}}$ と $\mathrm{X}_{\mathrm{k}}$ の関係

Fig-17 The relationship between selectivity coefficient $\left(\mathrm{K}_{\mathrm{Ca} / \mathrm{K}}\right)$ and molar fraction $\left(\mathrm{X}_{\mathrm{K}}\right)$

は $\mathrm{Ca}^{2+}$ に対する選択性がより高いことを意味する が、この傾向は一般に土壤有機物の $\mathrm{Ca}^{2+}$ に対する 選択性が高いことから説明できる ${ }^{13)}$ 。マサ土を主 体とする部分では、 $\mathrm{K}^{+}$のモル分率が $0 \sim 0.5$ の範囲
では $\mathrm{K}_{\mathrm{Ca} / \mathrm{K}}$ は比較的一定で $0.001 \sim 0.01$ 範囲にあ り、それ以上で急に増加した。 $\mathrm{K}_{\mathrm{Ca} / \mathrm{K}}$ が $\mathrm{K}^{+}$吸着量 の変化に伴って大きく変化することは多くの土壤や 粘土鉱物について報告されており ${ }^{14)}$ 、これらの多 


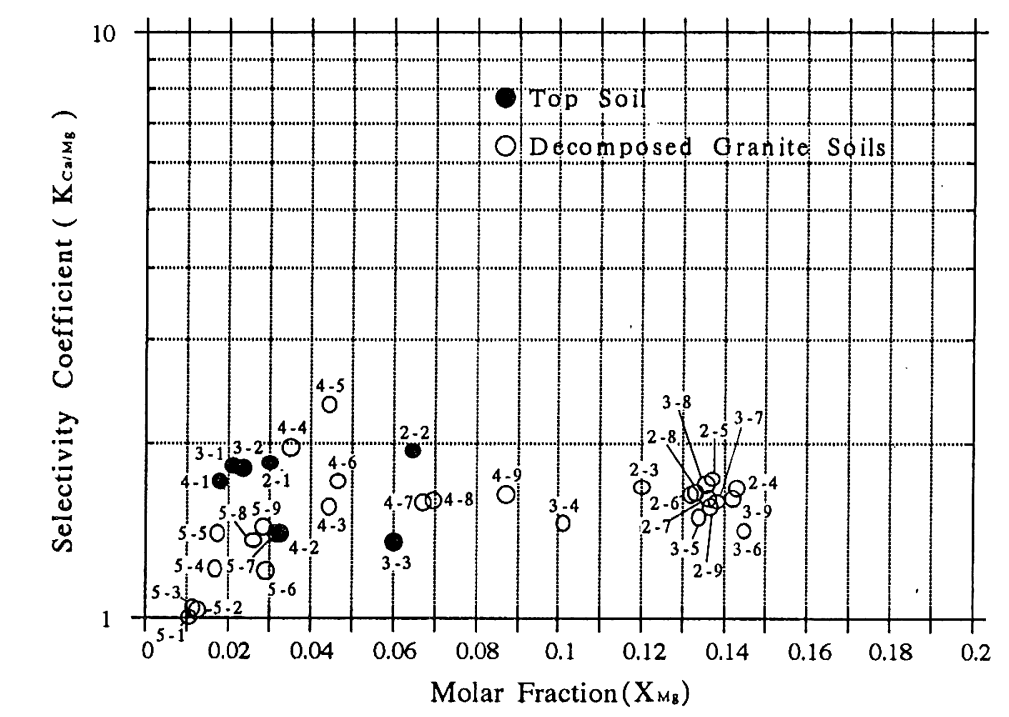

図-18 $\mathrm{K}_{\mathrm{Ca} / \mathrm{Mg}}$ と $\mathrm{X}_{\mathrm{Mg}}$ の関係

Fig-18 The relationship between selectivity coefficient $\left(\mathrm{K}_{\mathrm{Ca} / \mathrm{Mg}}\right)$ and molar fraction $\left(\mathrm{X}_{\mathrm{Mg}}\right)$

くは $\mathrm{Ca}-\mathrm{K} の 2$ 成分のイオン交換実験に基づいたも のである。本実験では 4 種の陽イオンが共存するが、 このような場合でも $\mathrm{K}_{\mathrm{Ca} / \mathrm{K}}$ が $\mathrm{K}^{+}$吸着量の変化に 伴って変化し、しかもその変化は $\mathrm{K}_{\mathrm{C} / \mathrm{K}}$ の值が $\mathrm{K}^{+}$ のモル分率に対して指数関数的に増加する傾向に なっていることから、 $\mathrm{K}^{+}$のモル分率のみの関数と して近似できることを示唆している。

図-18の $\mathrm{K}_{\mathrm{Ca} / \mathrm{Mg}}$ と $\mathrm{Mg}^{2+}$ のモル分率との関係では、 $\mathrm{Mg}^{2+}$ のモル分率は最大で0.15まで増加している。 これに対して $\mathrm{K}_{\mathrm{Ca} / \mathrm{Mg}}$ は 1 2 2.5の範囲内の值をとっ ていて、変動は非常に小さかった。また、この值は 一般的に言われている $\mathrm{K}_{\mathrm{Ca} / \mathrm{Mg}}$ の值である1.2に符合 している15)。

\section{6. まとめ}

本報で得られた知見は以下のと扔りである。この 系で起こる反応は主としてイオン交換によるもので あり、 $\mathrm{K}^{+}$を含んだ溶液を土壤表面に負荷すると $\mathrm{K}^{+}$は陽イオン交換反応によって固相に保持され、 従前より固相に保持されていた $\mathrm{Na}^{+}, \mathrm{Mg}^{2+}, \mathrm{Ca}^{2+}$ が液相中に放出され溶脱する。また、実験に用いた 畑地土壌の CEC は有機物質が含まれていると考え られる表層部と、マサ土が主体となっている下層部
とでは異なり、表層部での CECが下層部より大き な值を示した。即ち、CEC は土壤の種類によって 大きく值が変化することを示している。

次に、各陽イオンを基準にした $\mathrm{Ca}^{2+}$ の選択倸数 とそれぞれのモル分率との関係から、 $\mathrm{K}^{+}$のカラム 浸透に伴い、 $\mathrm{Ca}^{2+}, \mathrm{Mg}^{2+}, \mathrm{Na}^{+}$のモル分率は低下 し、 $\mathrm{K}^{+}$が卓越するようになる。異なる電価のイオ ン間の選択係数の值は变動が大きく、 $\mathrm{Mg}^{2+}$ を基準 にした $\mathrm{Ca}^{2+}$ の選択係数のみが、概ね 1 2.5 と安定 した值を示した。

一般的には現実の土壤において、多成分のイオン 交換平衡をモデル化するのは容易ではない。それは 選択係数が一定值をとるどころか、わずかなイオン 組成の変動により大きく変化することがあるからで ある。しかし、今回用いた土壤の場合には、第一に $\mathrm{Na}^{+}$の存在は無視できる程度であったこと、第二に $\mathrm{K}_{\mathrm{Ca} / \mathrm{Mg}}$ は土壤のイオン組成に関係なくほぼ一定值 を用いることができること、第三には $\mathrm{K}_{\mathrm{Ca} / \mathrm{K}}$ は吸着 $\mathrm{K}^{+}$のモル分率の関数として近似できること。この ような単純化を行えば、イオン交換反心を比較的容 易に物質輸送モデルに組み达むことができると考え られる。

今後は本実験で得られた結果をもとに、化学仪応 を加えた地下水中での物質輸送モデルの開発を行 
い、不飽和浸透流と多成分化学反応過程とを考慮し た水理化学的物質輸送解析を行う予定である。また、 本実験で得た選択係数とバッチ試験によるそれとの 違いなどについても今後検討する必要があろう。

\section{謝 辞}

本報をまとめるにあたり、カラム実験用の畑地土 壌を提供して下さった樋口重人様には多大な労力と 協力を、また福阔大学の山崎惟義教授には実験に関 する有益なアドバイスをいただいた。なお、本研究 の一部は(財)河川環境管理財団「地下水水質の循環 システムが表流水水質に及ぼす影響評価」（研究代 表者神野健二)の補助のもとに行われた。ここに深 く感謝の意を表します。

\section{参考 文 献}

1 ) 日本土壤肥料学会編：土埪の吸着現象一基礎と応用一、 博有社、1991.

2 )粐井和朗、細川土佐男、神野健二、伊藤敏朗：海㟁带 水層における鉛淔濃度分布に基づく横方向分散定数の推 定方法、土木学会論文集、411号/II-12、pp.45-53、 1989.

3 )藤䋥克之：污染される地下水、共立出版、1990.

4 )神野健二：地下水污染の解析とモニタリングの方法、 水工学シリーズ90-A-6,pp.A-6-1-A-6-25,1990.

5 ) Lai, S. and Jurinak, J. J:Cation Adsorption in OneDimensional Flow through Soils, Water Resources Research, Vol. 8, No. 1, pp. 237-259, 1972.

6 ) 神野健二: : 水理化学的物質輸送解析、応用地質 33 巻 3 号、pp. 35-45, 1992 .
7 )広城吉成、横山拓史、神野健二、和田信一郎、系井龍一、 山崎惟義、市川勉、細川土佐男：農耕地における地下水 水質の変動特性-特に除イオン濃度の変動について一、水 工学論文集第36巻、pp.403-408,1992.

8 ) Van Genuchten:A closed-form Equation for Predicting the Hydraulic Conductivity of Unsaturated Soils, Soil Science Society, 44, pp. 893-895, 1980.

9 )村本穣司、後藤逸男、䗷木翠：振とう浸出法による土 潩の交換性陽イオンおよび陽イオン交換容量の迅速分 析、日本土壤肥料学雑誌第 36 巻、第 2 号、pp.210-215、 1992.

10) A. L. Page, R. H. Miller, D. R. Keeney:METHODS OF SOIL ANALYSIS Part 2 -Chemical and Microbiological Properties, Second Edition, J. D. RHOADES:Cation Exchange Capacity, Soil Science Society of America, Inc. , pp. 149-151， 1982.

11)粐井和朗、矢野友久、神野健二、横山拓史、系井龍一、 広城吉成：多成分化学反応を考慮した地下水中の物質輸 送モデル、水工学論文集第35巻、pp.641-646、1991.

12) Sposito, G.:The future of an illusion, Ion activity in soil solutions, Soil Sci. Soc. Am. J., Vol.48, pp. 521-536, 1984.

13) Poonia, S. R. and Niederbudde, E. A.Exchange equilibria of potassium in soils, V. Effect of natural organic matter on K-Ca exchange, Geoderma, Vol. 47, pp. 233-242, 1990.

14) Bruggenwert, M . G . M . and Kamphorst, A . : Survey of experimental information on cation exchange in soil systems, In Soil Chemistry B . Physico - Chemical Models, Ed . G . H . Bolt, Elsevier , Amsterdam, pp. 141203, 1979.

15)Bolt,G.H. and Bruggenwert,M.G.M.(岩田進午、他訳)：土 壤の化学、学会出版センター、1980.

(受付：1993年 6 月 18 H、受理：1994年 1 月 7 日) 